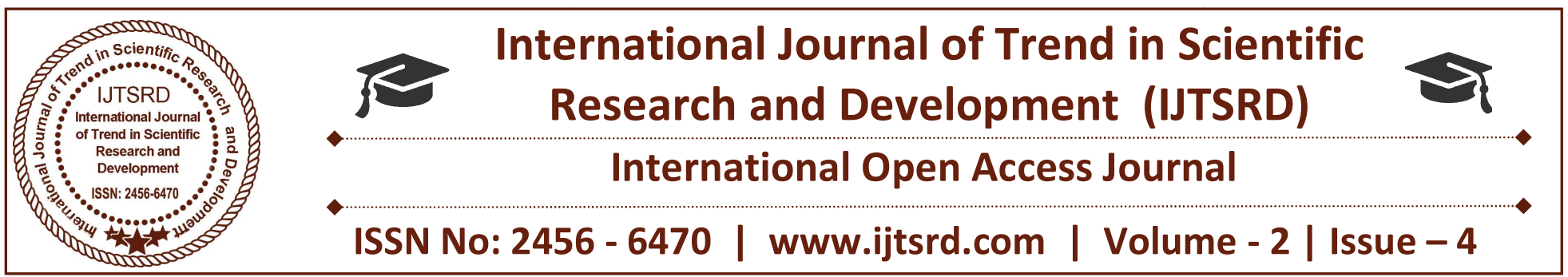

\title{
Green Marketing - A Step Towards Sustainable Growth
}

\author{
N. Paramesswari \\ Assistant Professor \\ Department of Management Studies \\ KG College of Arts and Science, Coimbatore, Tamil Nadu, India
}

\begin{abstract}
The paper is to study the concept of green marketing and its importance in environment and the government initiative. Green marketing has gained importance among the public due to non availability of resources and high price. All the resource are scarce and human wants are increasing green marketing has gained preference to satisfy them. Most of people are aware of environment protection and they are ready to compromise with the products they buy. Main aim of the study to know the challenges faces by companies to adopt green marketing. The data's are collected from websites and analysis are made to know the present trend in green marketing in India. The government is also taking initiative to green technology and to protect it by the regulations.
\end{abstract}

\section{INTRODUCTION:}

Green marketing is a process of selling products or services to safeguard the environment. According to The American Marketing Association, -Green or Environmental Marketing consists of all activities designed to generate and facilitate any exchanges intended to satisfy human needs or wants, such that the satisfaction of these needs and wants occurs with minimal detrimental impact on the natural environment. Green marketing must satisfy two objectives: improved environmental quality and customer satisfaction. Product or service may be environmental friendly by itself or it can be produced in an environmental friendly way, including:

$>$ Being manufactured in a sustainable fashion

$>$ Not containing toxic materials or ozone-depleting substances

$>$ Able to be recycled or it can be produced from recycled materials

Being made from renewable materials (such as bamboo, etc.)

Not making use of excessive packaging

$>$ Being designed to be repairable and not "throwaway"

Green marketing is the marketing of environmentally friendly products and services. It is becoming more popular as more people become concerned with environmental issues and decide that they want to spend their money in a way that is kinder to the planet.

Green marketing can involve a number of different things, such as creating an eco-friendly product, using eco-friendly packaging, adopting sustainable business practices, or focusing marketing efforts on messages that communicate a product's green benefits.

\section{Objective of study:}

The primary purpose of this study is to evaluate the need and implication of green marketing and also to evaluate the initiatives taken by the Indian government and concern for green marketing in their core business values.

\section{Research Methodology}

The study is exploratory in nature to provide a clear guidance for empirical research. Secondary data were used for the study. The secondary data were collected through newspapers, magazines, books, journals, conference proceedings, Government reports and websites.

\section{Review of Literature}

$>$ According to the American marketing association it has been interpreted or defined in three ways 1 . Retailing: the marketing of products that are 
presumed to be environmentally safe. 2 . Socially marketing: the development and marketing of products designed to minimize negative effects on the physical environment or to improve its quality. 3. Environment: the effort by organization to produce, promote, package and reclaim products in a manner that is sensitive or responsive to ecological concerns.

$>$ Pride and Ferrell (1993): green marketing, also alternatively known as environmental marketing and sustainable marketing, refers to an organization's efforts at designing, promoting, pricing and distributing products that will not harm the environment.

$>$ Polonsky (1994): defines green marketing as all activities designed to generate and facilitate any exchanges intended to satisfy human needs or wants, such that the satisfaction of these needs and wants occurs, with minimal detrimental impact on the natural environment.

$>$ Elkington (1994): defines green consumer as one who avoids products that are likely to endanger the health of the consumer or others; cause significant damage to the environment during manufacture, use of disposal; consume a disproportionate amount of energy; cause unnecessary waste; use materials derived from threatened species or environments; involve unnecessary use of or cruelty to animals; adversely affect other countries.

> Oyewole, P. (2001): he defines a conceptual link among green marketing, environmental justice, and industrial ecology. He argues for greater awareness of environmental justice in the practice for green marketing. In his paper he identified another type of costs, termed 'costs with positive results,' that may be associated with the presence of environmental justice in green marketing. A research agenda is finally suggested to determine consumers' awareness of environmental justice, and their willingness to bear the costs associated with it.

\section{Analysis and Interpretation}

\section{Green Marketing Mix}

\section{Green Product}

Products should be developed by the company which does not create any harm for customers. It should be produced from recycled materials or from used goods. Eco-friendly products not only save water, energy and money, but also reduce harmful effects on the environment. Green chemistry forms the growing focus of product development. The marketer's role in product management is to provide organic product to save environment.

\section{Green Price}

Green pricing takes into account the people, profit communities and ensures efficient productivity. Company can use additional cost if the customer opts for bags to avoid carry bags.

\section{Green Place}

Green place is to cut down the transportation emissions, thereby it reduce additional cost on buyers. If the company chooses the sellers locally it can reduce the cost of transportation and packaging.

\section{Green Promotion}

Green promotion involves company to make advertisement through mobile or web media or electronic display to have wide coverage. If companies choose green promotion it can avoid additional cost and it reach wide network. Eg: As a green bank imitative bank details can be seen in mobile phone and to avoid wastage of paper bank charge for slips printed.

\section{Challenges in Green Marketing}

\section{Need for standardization:}

Its true that only $6 \%$ of messages related to green marketing are true due to lack of standardization system in our country most of company misuse the term of organic and charge high price from customer. Regulatory bodies should be involved in providing the certifications there will not be any verifiable means. A good quality control board should be there to license and promote the products.

\section{New concept:}

Indian literate and urban consumer is more aware about the merits of green products. Indian customer should be educated and made aware of the environmental protection.

\section{Patience and Perseverance:}

The shareholders and company need to view the environment as important factor for long term investment opportunity, the marketers need to look at the long-term benefits from this new green movement. It needs a lot of patience and no immediate results can 
be achieved within a day. Since it is a new concept and idea, it will have its own acceptance period.

\section{Golden rules of Green Marketing}

1. Know your customer: If the company wants to sell green products to its customer, it should make them aware of the product that is promoted and its importance.

2. Empower consumers: Compant make sure that customers should feel by themselves or connected with others product should make difference is known as "empowerment" and it's the main reason why consumers buy greener products.

3. Be transparent: Consumers must believe in the product and the specific claims you are making. The rest of your business policies are consistent with whatever you are doing that's environmentally friendly.

4. Reassure the buyer: customers must be made to believe product will perform its specified quality and company has not compromised on the product performance in the name of environment.

5. Consider your pricing: most of the eco-friendly products are costly and company should make sure it should be affordable and worthy for purchasing it.

\section{Government Initiative for green technology:}

$>$ Government made initiatives to increase the use of electronic payment systems, and to gradually phase-out cheques and eliminate post-dated cheques in their routine business transactions as a part of "Green Initiative"

$>$ Protection and regeneration of forest and appliance, energy conservation building code and fuel emission norms for vehicle.

Government is imposing fine on Companies who sell plastic bags which harm environment.

\section{Challenges Ahead}

Most of the eco-friendly product need renewable and recycle material which is more in scare and costly.
$>$ Only large scale concern can go for green technology because of huge investment in research and development and investment.

Most of customer is not ready to afford more cost for green product due to lack of awareness.

Majority of the company label themselves as organic and sell product government should take imitative to have special department for registration to sell eco-friendly product.

\section{Conclusion:}

Considering the importance of the environment for human beings, the concept of green marketing/environment friendly marketing and sustainable development is getting attention in India with time, but it is still at a nascent stage. The Government has already announced and implemented various policies and regulations for environmental protection, whereas various organizations are willingly adopting environment friendly practices but the problem is with small firms in adopting because they are concern with short run profits. For such organization forceful implementation is required by government Consumer awareness must be created by corporate by transmitting the message among consumers about the benefits of environmentalfriendly products and services.

\section{References:}

1. Mittelman. Robert . Green consumer behaviour in emerging market: A review of research

2. Bhowmick. Tanushree . Green marketing - An analysis of consumer behaviour towards green products.

3. Awan, Usama and Raza , Muhammad A, . Green consumer behavior : Empirical study of Swedish consumer behavior.

4. http://www.greenmarketing.net/strategic.html

5. 5.http://en.wikipedia.org/wiki/Green_marketing 